\title{
O "RÉU SEM ROSTO"
}

\author{
David Teixeira de Azevedo \\ Professor Doutor do Departamento de Direito Penal, \\ Medicina Forense e Criminologia da Faculdade de \\ Direito da Universidade de São Paulo
}

\begin{abstract}
Resumo
Este trabalho apresenta as mais recentes discussões em torno da "Justiça

Cibernética".
\end{abstract}

Abstract

This paper presents the recents discussions about the Cybernetic Justice.

Unitermos: Poder Judiciário brasileiro; Justiça Cibernética; réu sem rosto.

As dolorosas perdas dos juízes Antônio José Machado Dias, Juiz de Direito no Estado de São Paulo, e Alexandre Martins de Castro Filho, Juiz de Direito no Estado de Espírito Santo, despertaram no Poder Judiciário brasileiro a sensação de fragilidade. O gigantesco aparelho de exercício de poder pelo Estado foi tomado pelo medo. Mais: por verdadeiro pânico. Sob pânico, a razão perde o bom norte, sai mesmo de seu demarcado território, e as respostas são emocionais quando não instintivas. Sob o império do instinto não há discernimento intelectual, não há valoração racional, não existe o tempero da piedade, a sensibilidade da dor do outro. Aliás, não existe nem mesmo o outro, pois é o instinto autocentrado e auto-referente.

As propostas excogitadas para solução da violência sobre membros do Poder Judiciário e as idéias brotadas para permitir o regular funcionamento da Justiça, ainda envolvida pelo clima da morte dos magistrados, vêm dominadas pelo pânico. São propostas e idéias de um lado ilógicas e de outro, na perspectiva do relacionamento Estado-cidadão, uma reação instintiva de aniquilamento do outro.

Pensar em policiais militares como uma espécie de guarda-costas do magistrado é absolutamente ilógico.

Primeiramente porque essa proteção deverá ser feita 24 horas por dia, 365 dias por ano, pois assassinos contratados e Comandos Criminosos não escolhem dia e hora para concretizar a ofensa. Fazem campana, escolhem a melhor oportunidade. 
Um passeio aos finais de semana ao supermercado, ao shopping, ao cinema, uma viagem, uma festa, enfim um momento de descuido e a vida é ceifada.

Em segundo lugar, não há no contingente da Polícia Militar.de São Paulo pessoal para cobertura de todos os magistrados, da Vara Comum e dos Tribunais, no rodízio de 24 horas. Isto implicaria destacar quatro policiais para cada magistrado. São Paulo, p. ex., contando com aproximadamente 2 mil magistrados, deveria separar perto de 8 mil policiais, ou seja, perto de $20 \%$ de todo o efetivo da Polícia Militar, excluídos os Policiais Rodoviários e os Bombeiros. E se a ameaça se estendesse aos promotores, como, aliás, já ocorreu com ilustres membros do Ministério Público alvejados na via pública, esse número praticamente duplicaria.

Em terceiro lugar, há o envolvimento de maus policiais com o crime organizado, cuja dramática ilustração, em tinta vermelha, foi a brutal morte do juiz das Execuções Penais Alexandre Martins de Castro Filho: o coronel PM Walter Gomes Ferreira, preso na distante Penitenciária de Papudinha no Acre, foi o mandante do assassinato do magistrado. Nessa perspectiva, estar sob a proteção da Polícia Militar pode, eventualmente, significar achar-se o magistrado sob maior e mais qualificado risco. Risco que poderá inclusive provir da falta de capacitação do policial, não treinado para defesa pessoal de terceiro, o que é um contigente muito pequeno. Um policial destacado para acompanhar um magistrado, amigo, do Tribunal de Alçada Criminal disse, em tom de séria brincadeira, ser o primeiro a fugir.

Outras dessas idéias destituídas de toda lógica intrínseca, que apressadamente se busca transformar em lei tão-só para oferecer à população a sensação de que providências urgentes são agilizadas, diz respeito ao isolamento celular por 365 dias ou mais do recluso e o aumento da reprimenda para homicídio cometido contra membros do Poder Judiciário, do Ministério Público e da Polícia, por exemplo.

O isolamento celular é a um só tempo inutilidade e desumanidade. Nem mesmo se pudessem ser colhidos reais e proveitosos frutos dessa violência à dignidade da pessoa humana, ou mesmo se dessa negação dos direitos naturais mínimos do preso resultasse eficaz controle do crime, nem assim essa estúpida idéia se justificaria.

Nada. O preso verdadeiramente, pelo teor da norma, terá direito a dois celulares: ao isolamento celular e ao aparelho celular para comunicação com o exterior. O conflito lógico da lei é visível. A primeira premissa afirma entrarem celulares nas Penitenciárias, apesar de terminantemente proibidos. A segunda premissa afirma ser a lei descumprida pela corrupção que grassa "leve e solta" e graças à qual os presos têm 
acesso a celulares, com os quais "trabalham" como executivos, em comunicação constante com o exterior, a agenciar e administrar a prática de crimes.

A conclusão lógica "perneta" não é a de impedir o ingresso de celulares, nem a de combater a corrupção no sistema penitenciário. A brilhante conclusão, de "lógica burra" é a de que se o preso tem acesso ao celular dentro de sua cela comum, em decorrência da corrupção no sistema, ele deixará de ter acesso ao celular se ficar recluso na cela ou for transferido para outra. Assim os celulares deixariam de ingressar na prisão e/ou a corrupção estaria debelada !!? Não é apenas falta de lógica, mas má-fé manifesta de uns e uma inocência injustificável de muitos outros.

Que relação lógica pode haver entre corrupção que permite ingresso de celular na cadeia e réu isolado? Porventura não está ele no ambiente carcerário? E estando nesse ambiente não aproveitará de sua fragilidade para obter o celular?

Se lógica há, ela é perversa. A corrupção gera a comunicação celular. Não se debela a corrupção e se oxigeniza moralmente o sistema, mas se cerceia o direito mínimo do preso de contato com o exterior! Parece mais fácil e simples afligir o direito do cidadão preso ou solto - não importa -, do que o Estado tomar providências administrativas para solução dos problemas de sua exclusiva responsabilidade.

Valem a esse propósito, como lição, as palavras da coordenadora da Pastoral Carcerária no Estado do Espírito Santo, Isabel Borges da Silva: "Não existe presídio de segurança máxima enquanto tivermos corruptos dentro dos nossos Poderes Judiciário e Legislativo e do sistema penitenciário. Aqui o crime está institucionalizado"

De qualquer modo, penso que ao final e ao cabo ganhará nosso executivo do crime maior privacidade para desempenhar suas tarefas, o que não deixa de ser, de algum modo, um respeito ao direito à intimidade, ao direito de estar só!

O Estado sofre de amnésia institucional ou de vício grave político. A amnésia total institucional faz esquecer o legislador-carcereiro da edição em 1990 da Lei dos Crimes Hediondos. Essa legislação elevou a pena mínima do crime de extorsão mediante sequiestro de seis para oito anos de reclusão e outra coisa não aconteceu senão o aumento dessa modalidade de infração penal. Enquanto em 1996 houve doze crimes de extorsão mediante seqüestro, em 1999 esse número subiu para dezenove, em 2001 para 307 e em 2002 para 321 !

Outro tanto sucede com o crime de homicídio, em que a modalidade qualificada também incluída entre os crimes hediondos. Do total de homicídios em

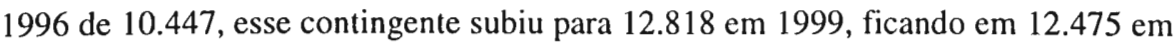
2001 e fixando-se em 11.847 em 2002. 
Já com relação ao crime de latrocínio, também identificado como hediondo e com penas exacerbadíssimas, houve um total de $524 \mathrm{em} \mathrm{1996,450 \textrm {em }}$ 1997, 562 em 2001 e 505 em 2002.

A Secretaria da Segurança Pública do Estado de São Paulo revelou a razão da diminuição havida nos delitos de extorsão mediante seqüestro em 2002: melhoria do policiamento preventivo e repressivo; criação de delegacias especializadas e aumento do contingente de policiais e modernização dos equipamentos.

Por isso, é mais que condenável o vício político de jogar com os números da criminalidade e propor leis duras em profusão para alcançar coeficiente político. Os estelionatários do poder querem enganar a população para granjear a indevida vantagem: prestígio político e votos. Sabem que a criminalidade não diminuirá, sabem que a prática de crimes contra magistrados, membros do Ministério Público e da Polícia não depende da incriminação penal. Não-obstante, jogam para a platéia. Encenam. Posam de responsáveis e oferecem a solução fácil de alteração legislativa como capaz de forjar uma nova realidade.

Na melhor op̧̧ão, é amnésia. Na pior, má-fé explícita, hard core.

O pânico não gera apenas idéias ilógicas ou paralógicas e de sofistaria. Incita e excita os instintos e gera o embrutecimento da alma. Essa, a idéia do "Juiz sem Rosto" uma autenticação da impessoalidade da Jurisdição Penal, uma despersonalização da Justiça Penal, que deixa de ser o palco dos dramas da vida, da dor trágica do crime, da compulsão do criminoso e da participação menor ou maior da vítima, que deixa de ser o sítio de realização e problematização de valores para degenerar-se numa atividade mecânica, desenvolvida dentro de um sistema asséptico. O que sobra é a pasteurizada presença do juiz, com distanciamento do réu (já há o interrogatório on line), com o véu voltado para a vítima, escondido das testemunhas, distante do pulsar da existência. Já agora não a figura tão criticada do juiz-de-gabinete, mas a figura do juiz sem rosto, sem figura, sem forma, sem feição, sem emoção, sem paixão e sem Justiça.

O Juiz-sem-rosto, a bem ver, viola o direito de defesa. Já não se poderá apreciar, pelos traços fisionômicos e mudança de semblante se a prova colhida está ounão interferindo no convencimento judicial e em que medida, porquanto o ato de comunicação e de persuasão vai muito além da letra deformada dos autos. Fere, sob outro ângulo, o direito à publicidade, pois não conhecerá o réu, nem os partícipes do processo, nem os cidadãos qual o juiz da causa. É uma justiça secreta, exercida por um espectro ou por um juiz fugidio. 
É preciso acautelar-se não apenas da despersonificação do juiz, mas de todos os atores do processo. O fenômeno do "Juiz-sem-rosto" pôs o facho luminoso sobre o palco processual para iluminar um ator há muito tempo sem semblante: o réu.

O "Réu-sem-rosto" este personagem sem personalidade, este homem sem vida no processo, é o resultado de uma justiça criminal de alma endurecida ou embrutecida, que vive sob o encantamento produzido pela natureza do crime (violento e dirigido ao patrimônio).

Esse encantamento, que magnetiza o operador do direito, primeiramente esmaece ou faz desaparecer da cena processual o acusado, sua história e seus laços sociais, depois relativiza as provas (um cortejo delas já não-absolve, mas um fiapo lastreia o juízo condenatório), e, por fim, aqui o mais grave, subverte os princípios processuais e penais democráticos.

Outro dia, ao aguardar oportunidade de sustentação em Tribunal de Justiça estadual observei a realidade crua do réu-sem-rosto. Nenhum, mas nenhum mesmo habeas corpus foi concedido quando o delito era de natureza patrimonial praticado mediante violência ou grave ameaça, como o roubo ou a extorsāo mediante seqüestro, ou, ainda, crimes que ferem o preconceito judicial como o de tráfico de entorpecente. Todavia, ordens foram concedidas, às mancheias, precedidas ou-não de liminares, quando a imputação era de crime de falso, contra o consumidor, estelionato ou até mesmo contra a vida.

O mais horrendo já começa a surgir: negação de vigência de textos legais. Inúmeros julgados têm negado vigência a textos expressos de lei. Assim p.ex. ocorre nos denominados crimes praticados mediante organização criminosa, que são os delitos praticados por meio de quadrilha ou bando, já que nossa legislação não definiu corretamente o que seja organização criminosa. Não-obstante o texto expresso e claro da lei fixe o prazo de 81 dias para o término da instrução criminal do réu preso e 120 dias quando solto, simples e reincidentemente se desconsidera o texto legal.

E não fique o cidadão feliz pelo descumprimento da lei sob a falsa idéia de assim se achar mais seguro, pois the aproveitaria a prisão sem fim do réu ou indiciado. Amanhã poderão ser os direitos do cidadão aqueles os esquecidos da toga. E o cidadão acha-se mais próximo do réu do que do juiz. O cidadão certamente poderá ser réu um dia, tem grande e real probabilidade de sê-lo. A imensa maioria, porém, nunca será juiz, a participar do poder do Estado. É bom, portanto, querer juízes com rosto, sentenças assinadas, direitos respeitados e a lei observada. Disso tudo depende a democracia. 
Retomando, o réu já está sem rosto há muito tempo, sendo por isso indeferidas as perguntas dos defensores relativas aos antecedentes do acusado, sua vida social e familiar, seu engajamento em obras relevantes para a comunidade. Tudo isso a maioria dos juízes tem por irrelevantes "porque não dizem com o fato objeto do processo, doutor" Já não vale a redação do art. 59 do Código Penal, segundo a qual o juiz aferirá o juízo de culpabilidade levando em conta os antecedentes, a motivação, a conduta social, as circunstâncias do crime e conduta da vítima!

Reprise-se. O réu já está sem rosto há muito tempo e, agora, parece o kairós de o Juiz perder o rosto e com ele perder a Jurisdição a identidade própria. A impressão é de que o Estado aguardava essa oportunidade. Do relacionamento de um juiz-sem-rosto com um réu-sem-rosto muito pouco ou nada se pode esperar da atividade quase sacra de realização da Justiça.

Melhor seria - talvez houvesse mais Justiça - os excelentes engenheiros ou técnicos de sistema criarem um cuidadoso programa de valoração de provas, capaz de aferir criteriosa e matematicamente tarifa à prova e à palavra do réu, agora reduzida a simples letra, balancear os argumentos de acusação e defesa e proferir uma decisão qualquer. Enfim, melhor seria - e com que dor afirmo - uma justiça cibernética, de simples controle de máquinas e não de homens, porque a elas foram degenerados os humanos decaídos que pecam e os inumanos, sob máscara ou capuz, que julgam.

São Paulo, novembro de 2003. 